\title{
Relationship between Outdoor Classroom Environment and Provision of Quality Education in Public ECDE Centres in West Pokot County, Kenya
}

\author{
Mildred C. Chepkonga \\ Doctorate Student - University Of Eldoret, Kenya P.O. Box 1125-30100 Eldoret, Kenya
}

\begin{abstract}
Learning instruction in Early Childhood Education setting requires that pupils interact with their environment while learning various activities. The purpose of writing paper was to investigate how outdoor classroom environment setting influenced provision of quality education in public ECDE centres in West Pokot County, Kenya. The study was conducted through descriptive research design. The respondents for the study involved ECDE teachers, head teachers and education officers. The sample size for the study was arrived at by taking 10-30\% of the target population to act as the sample size that is 10\% for head teachers and $30 \%$ for ECDE teachers. The study used questionnaires, interview guide and observation as instruments for data collection. The instruments used were tested for validity and reliability prior being administered to the field. The research results showed that there was significant relationship between outdoor learning environment and provision of quality education $(p<0.01)$. The study concluded that children regular participation in outside classroom activities, quality of education improved. The study suggests that schools should invest in purchase and fixing of sports equipments in their compounds, the administration of the schools to make initiatives of levelling the playing service and the environment around the school should be fenced well to avoid intruders into the school compound who come to disrupt outdoor activities sometimes.
\end{abstract}

Keywords: outdoor, learning, environment, sports, compound, fence, quality, education

\section{Introduction}

According to the World Education Forum (2000), quality can be viewed from various perspectives namely: in terms of input of process and in terms of results. Provision of quality education is also seen through content that is reflected in relevant curricula and materials for the acquisition of basic skills, especially in the areas of literacy, numeracy and skills for life, and knowledge in such areas as gender, health, nutrition, HIV/AIDS prevention and peace (Mwende, 2014). Quality early childhood education is characterised by appropriate child teacher ratios and group sizes, appropriately qualified and trained teachers and education workers, and enriching, well equipped, caring and secure environments in approved and accredited locations, all of which should be defined and enforced by regulation. This research will look at how outdoor learning environment influence provision of quality education in public ECDE centres in West Pokot County, Kenya.

ECDE learning can occur anywhere (indoor \& outdoor classroom) but the positive learning outcomes generally sought by educational systems happen in quality learning environments (Worthington, 2008). Learning environments are made up of physical, psychosocial and service provision elements (Mwamba, 2013; Muthoni, 2013; OECD, 2013). The environment must nurture children's capacity to engage deeply in individual and group activities and projects (Fuller, 2009). Abiero (2013) observed that most pre-primary education programs suffer from poor quality services. Mutuma (2015) noted that early childhood education has, for a long time, been at the periphery of the education programming in Kenya. It was formerly considered as social rather than an education activity. There are no specific budget allocations for ECE, except for school inspection and minimal amounts for teacher training. This has led to majority of preschool children to learn in deplorable conditions (Boke, 2014). The Kenyan government has so far developed a guideline on early childhood development quality service standards through NACECE. This is meant to guide on effective and efficient provision of Education in both public and private ECD Institutions (RoK, 2012). However, the implementation of these guidelines has been a problem due to many challenges that ECDEs are facing in Kenya. Very few of ECDE centres have attained full implementation of such services (Mutuma, 2015). Many have not especially in West Pokot County and other northern Kenyan counties.

\section{Problem Statement}

West Pokot County being the focus of this study faces challenges related to quality education provision for pre-primary, primary and secondary education due to; food insecurity, cultural nomadism, insecurity along the borders, aridity and low socio-economic development (Mutuma, 2015). For instance, Uwezo (2012) report on West Pokot County found out that there was notable decrease in learning levels of children in the county. 
Only half of the children in class three were able to read a paragraph or do subtraction. The number of preschool children attending school decreased.

\section{Aim of the Study}

The aim of this paper is to examine ways through which outdoor learning environment influence provision of quality education in selected public ECDE centres in West Pokot County, Kenya.

\section{Research Hypothesis}

The paper was guided by the following hypothesis:

$\mathrm{H}_{04}$ There is no significant relationship between outdoor classroom environment and provision of quality education in public ECDE centres

\section{Assumptions of the Study}

(i) Learning environment does not encompass climate or weather patterns

(ii) All pre-school teachers participated in answering all the questions of the study

\section{Conceptual framework}

Figure 1.1 here below shows the conceptual framework for the study:

\begin{tabular}{|c|c|}
\hline Independent Variable & Dependent Variable \\
\hline $\begin{array}{c}\begin{array}{c}\text { Outdoor classroom } \\
\text { environment } \\
\text { - School fence }\end{array} \\
\text { - Teacher playing with pupils } \\
\text { outside } \\
\text { - Playing equipments fixed in } \\
\text { the compound } \\
\text { - Time for outdoor activities } \\
\text { - Condition of school } \\
\text { compound and playing } \\
\text { surfaces } \\
\text { - Engagement in environmental } \\
\text { activities }\end{array}$ & $\begin{array}{l}\text { Provision of quality } \\
\text { education } \\
\text { - Acquisition of numeracy } \\
\text { and literacy skills } \\
\text { - Demonstration of } \\
\text { initiative, engagement and } \\
\text { persistence } \\
\text { - Children have Ability to } \\
\text { solve problems } \\
\text { - Children show creativity } \\
\text { and imagination. } \\
\text { - Transition rate }\end{array}$ \\
\hline
\end{tabular}

Figure 1.1 Conceptual framework

\section{Theoretical Literature}

\section{Review of Literature}

Haile (2010) stated that the physical organization of the indoor space is important but no pre-school environment is complete without taking in to account the outdoor area. The two make total learning environment, which caters for every child's interests and provides materials that will be appropriate for the level of development of each child. It is important to consider the classroom environment as children spend a considerable portion of their day in a classroom (Worthington, 2008). Four factors; classroom arrangement, expressing the value and acceptance of diversity of all children, routine activities and language rich environment have been suggested as key to a quality environment for young children, especially ELs (De Bruin-Parecki, 2008; Greenberg \& Rodriguez, 2007).

Curtis (1998) suggested the main requirements of outdoor play area to facilitate, learning primarily it must be safe and secure with ample space for the children to play freely, preferably with trees, flat grass areas and bushes where children can hide-and-seek and play in the mud. If the pre-school is attached to a primary or secondary school then it is important that the play area is separated from the older children. The outdoor equipments should provide children with a wide variety of opportunities for active physical experience; wood, boxes, crates, planks, and so on will enable children to build interesting structures which will serve as triggers to imaginative play. To ensure the safety of children in ECDE Centres, Chowdhury and Choudhury (2002) recommended a nursery school or pre-school which must have a playground close to the building. The outdoor play space and playground must be safe and secure for the children to play freely. It should be free from nails, rocks, broken parts, edges and glass places. The area should be well-fenced, drained, and surface materials should be appropriate for the activities in the area.

Developmentally appropriate play grounds include a variety of equipments and materials selected on the basis of the age characteristics and individual differences in abilities of the users selected materials and equipment must support the types of play we observe in children (Haile, 2010). Moreover, outside play allows 
for more active play with fewer restrictions on noise and movement, and greater freedom with natural materials like water, sand, snow, and soil. Also children revel in the variety inherent in the seasonal changes. Contemporary playgrounds also foster dramatic play. These outside learning settings have large, multi-stationed equipments that may include; house-type enclosures, nets, poles, slides, tire swings, bridges, and stairs. Since a number of children can use these types of equipments concurrently, social interaction is likely and children often develop dramatic play themes. Children sometimes have the opportunity to bring loose parts to contemporary playground settings, thereby increasing play themes (Maxwell, Mitchell \& Evans, 2008).

Broekhuizen, Scholten and de Vries (2014) indicated that preschool environment is an important setting to improve children's health. Especially, the pre-school playground provides a major opportunity to intervene. The researchers presented an overview of the existing evidence on the value of both school and preschool playgrounds on children's health in terms of physical activity, cognitive and social outcomes. The study indicated that among ECDE children, mainly hardware and orgware playground characteristics like increased playground size, decreased playground density, and increased recess duration were associated with an increase in physical activity level during recess.

Providing a quiet area be recommended as a developmentally appropriate practice (Kostelnik, Soderman, \& White, 2007) activity that are more active can be emotionally and physically demanding and quiet areas provide children with the option and opportunity to take a break. It is also recommended that areas should be created to provide EL children with a safe haven, an area that the children may engage in a quiet activity that does not require interacting with others (Tabors, 2008). Tabors suggests safe havens include items such as small construction activities, puzzles, and play dough, that will provide learners with a sense of independence, and feeling comfortable and competent, and engaged. Assefa (2014) adds that many of the skills and competencies which develop during those early years are learned from the outdoor natural environment children will gain more from digging in the garden and watching worms and insects than they will form looking at pictures. Sitati et al (2016) argues that Children learn better through play, discovery and imitating. This is only possible if the appropriate and adequate play equipment and materials are provided to the children. Facilities that meet the needs and interest of the child should be provided and the learning environment and materials should be childfriendly, brightly coloured and suitable for the age of the child. This makes learning interesting and fun, motivating the child to love learning.

\section{Empirical Literature}

Maxwell, Mitchell and Evans (2008) investigated (in two stages), ways in which playground equipment and the addition of loose parts to a playground contributed to ECDE children's dramatic and constructive play behaviours. For 10 months they observed that children attending a lab ECDE as they played on large, multistation outdoor play structures in order to identify design features of outdoor play equipment that encourage particular play behaviours and social interaction. The environmental design features that buoyed imagination play were enclosed spaces with visibility to other areas of the playing ground, nodes and connector spaces, and stage-type spaces. Boys engaged in more useful play while girls engaged in more imagination play. The second study, conducted with the same lab preschool but different children, tested the effects of a design intervention on the playground. Maxwell et al, (2008) added loose parts suitable for constructing spaces to the playground and they observed pupil's play behaviour before, during and after the intervention. It was found out that constructive play behaviour increased in the areas of the playground to which they had added the loose parts. Children used the places they constructed for dramatic play activities. The second study confirmed findings from the first study that young pupils liked to act out dramatic play themes in small, enclosed spaces. In the second study, children were able to construct their own spaces, which not only encouraged dramatic play but also communication and negotiation skills. The result by Maxwell et al, (2008) was experimental study while this research was descriptive determining the influence of playing grounds on provision of quality education in pre-schools.

Kofi (2012) compared pre-school provision in public and private schools with a focus on Ayigya MA and the KNUST Nursery schools as a case study. Data gathered revealed that pupils who were able to write the full set of the 26 English alphabets in the written test conducted constituted 8\% in Ayigya MA School as against $40 \%$ in KNUST Nursery School. There was significant disparity in the experiences of the children, teacher expertise and experience, academic and play facilities coupled with differences in the social and economic backgrounds of children from Ayigya MA and KNUST Nursery schools. In Nigeria, Okudo and Omotuyole (2014) investigated the impact of enhanced learning environment and its implications on the language development and achievement of the pre-school children. Questionnaire was the instrument used to elicit data from one hundred and fifty five pre- school teachers. Findings of the study depicted that the environment of the pre-school children should provide nourishment for the children's language and overall development and that the content and their learning styles should be quite different from those of the adults. 
Macharia (2012) examined the influence of school playground safety on the participation of preschool children in outdoor activities in Central Division, Naivasha District, Kenya. The study adopted a descriptive survey design to explore how playground space safety, developmentally-appropriate playground equipment, playground surfacing, playgrounds maintenance inspection and the supervision of children in the playground influence the participation of pre-school children in outdoor activities. The results of the study showed that despite the many constraints that make it impossible to ensure total playground safety, children continue to use the playgrounds for outdoor activities. The results also revealed that a combination of adequate, orderly and well organized playground spaces, developmentally-appropriate play equipment, proper playground surfacing, regular and adequate playgrounds maintenance inspection and properly organised supervision of children in the playground enables preschool children to effectively participate in outdoor activities. Sitati, Mwangi, Kennedy and Rapongo (2016) investigated the implementation of the ECDE service standard guidelines on provision of physical facilities in ECE centres in Kakamega County. A descriptive survey design was adopted. Head teachers and ECE teacher were the study subjects. Structured questionnaires were used to collect data. The instruments were validated through expert judgement and pilot testing. The findings revealed that there were no significant differences in adherence to the government guidelines in provision of classrooms and furniture. Nonetheless, significant differences existed between the two categories in adherence to the government guidelines in provision of water and sanitary and play facilities.

\section{Material and Methods}

The study was conducted in selected public ECDE centres in West Pokot County, Kenya. The researcher chose the study area to investigate the effect of learning environment on learning process due to report by Uwezo Kenya (2012) that showed that more than $68.9 \%$ of learners joining class four were not able to read and write in West Pokot County. This study was a descriptive survey because the population is large covered in four sub-counties. The purpose of descriptive survey research is to describe specific characteristics of a large group of persons, objects or institutions (Oso \& Onen, 2009).

Table 1 Target and Sample Population

\begin{tabular}{|c|c|c|c|c|c|c|c|}
\hline \multirow[t]{2}{*}{ Sub-counties } & \multicolumn{3}{|c|}{ Head teachers } & \multicolumn{3}{|c|}{ ECDE teachers } & \multirow{2}{*}{$\begin{array}{c}\text { DICECE } \\
\text { officers }\end{array}$} \\
\hline & $\mathbf{N}$ & formula & $\mathbf{n}$ & $\mathbf{N}$ & formula & $\mathbf{n}$ & \\
\hline South Pokot & 67 & $* 0.1$ & 7 & 134 & $* 0.3$ & 40 & 1 \\
\hline Central Pokot & 128 & $* 0.1$ & 13 & 213 & $* 0.3$ & 64 & 1 \\
\hline West Pokot & 128 & $* 0.1$ & 13 & 256 & $* 0.3$ & 77 & 1 \\
\hline North Pokot & 42 & $* 0.1$ & 4 & 79 & $* 0.3$ & 24 & 1 \\
\hline Total & 365 & & 37 & 682 & & 205 & 4 \\
\hline
\end{tabular}

Probability sampling technique included use of stratified random sampling. This method was used to select head teachers and ECDE teachers in each Sub County. For DICECE officials non-probability sampling method of purposive sampling method was used since they are the ones involved in supervising and evaluating the provision of ECDE education programme in their respective areas. Data for this research was collected through use of questionnaire for teachers, interview for head teachers and DICECE officers and researcher observation. The instruments were tested for validity through expert judgement and test retest reliability using Pearson correlation coefficient. Data collected was analysed using descriptive and inferential statistics.

\section{Results}

Influence of Outdoor Classroom Environment on Provision of Quality Education in Public ECDE Centres

The main objective of the study sought to determine the influence of outdoor classroom environment on provision of quality education in public ECDE centres in West Pokot County. Through statements measured in Likert scale of five (strongly disagree, disagree, undecided, agree and strongly agree), the teachers were asked to indicate their opinion. The results of the analysis are given in Table 2.

Table 2 Influence of Outdoor Classroom Environment on Provision of Quality Education

\begin{tabular}{|c|c|c|c|c|c|c|c|c|}
\hline Variable $(n=205)$ & & SD & D & $\mathbf{U}$ & $\mathbf{A}$ & SA & Mean & SD \\
\hline I regularly play with pupils outside the & $\mathbf{f}$ & 19 & 10 & 15 & 109 & 52 & \multirow{2}{*}{3.8049} & \multirow{2}{*}{1.15086} \\
\hline classroom & $\%$ & 9.3 & 4.9 & 7.3 & 53.2 & 25.4 & & \\
\hline Surfaces of outdoor play areas are free & $\mathbf{f}$ & 40 & 95 & 16 & 29 & 25 & \multirow[b]{2}{*}{2.5317} & \multirow[b]{2}{*}{1.28918} \\
\hline $\begin{array}{l}\text { from sharp objects, harmful plants and } \\
\text { discarded materials and equipment }\end{array}$ & $\%$ & 19.5 & 46.3 & 7.8 & 14.1 & 12.2 & & \\
\hline The school compound is safe and securely & f & 33 & 99 & 16 & 26 & 31 & \multirow{2}{*}{2.6244} & \multirow{2}{*}{1.31372} \\
\hline fixed with playing equipments & $\%$ & 16.1 & 48.3 & 7.8 & 12.7 & 15.1 & & \\
\hline The school is fenced around to provide & f & 18 & 24 & 69 & 71 & 23 & \multirow{2}{*}{3.2780} & \multirow{2}{*}{1.09175} \\
\hline security and minimise interference from & $\%$ & 8.8 & 11.7 & 33.7 & 34.6 & 11.2 & & \\
\hline
\end{tabular}


Relationship between Outdoor Classroom Environment and Provision of Quality Education...

\begin{tabular}{|c|c|c|c|c|c|c|c|c|}
\hline \multicolumn{9}{|l|}{ outside } \\
\hline We sometimes conduct our lessons outside & $\mathbf{f}$ & 10 & 11 & 14 & 126 & 44 & \multirow{2}{*}{3.8927} & \multirow{2}{*}{.96416} \\
\hline the classroom to interact with nature & $\%$ & 4.9 & 5.4 & 6.8 & 61.5 & 21.5 & & \\
\hline We have enough playgrounds for our & $\mathbf{f}$ & 17 & 24 & 33 & 43 & 88 & \multirow{2}{*}{3.7854} & \multirow{2}{*}{1.32945} \\
\hline pupils & $\%$ & 8.3 & 11.7 & 16.1 & 21.0 & 42.9 & & \\
\hline \multirow{2}{*}{$\begin{array}{l}\text { We regularly engage pupils in } \\
\text { environmental activities of cleaning the } \\
\text { compound, collecting trash and even } \\
\text { planting flowers/trees }\end{array}$} & f & 22 & 28 & 13 & 89 & 53 & \multirow[b]{2}{*}{3.6000} & \multirow[b]{2}{*}{1.29706} \\
\hline & $\%$ & 10.7 & 13.7 & 6.3 & 43.4 & 25.9 & & \\
\hline Composite mean & & & & & & & 3.3596 & 1.20517 \\
\hline
\end{tabular}

Key: SD-Strongly Disagree (1), D-Disagree (2), U-Undecided (3), A-Agree (4) and SA-Strongly Agree (5)

Table 2 shows that most 109 (53.2\%) of teachers agreed that they regularly played with pupils outside the classroom during co-curricular activities. The result show that most $(\mathrm{M}=3.80$ and $\mathrm{SD}=1.15)$ teachers played with their pupils outside classroom as required by curriculum for co-curricular activities. The above responses shows that teachers create a pleasant atmosphere in ECDE by regularly playing with their children outside the classroom for the purpose of ensuring that they meet the extra-curriculum goals. Dewey (1857-1957), the father of child-friendly school, supported the idea of children learning through play. When asked as to whether surfaces of outdoor play areas were free from sharp objects, harmful plants and discarded materials and equipment, $95(46.3 \%)$ disagreed. The result implies that majority $65.8 \%$ of teachers agreed that their school compounds were not smooth as they had sharp objects (thorns and stones) that prevented pupils from participating in outdoor activities on regular occasions. The computed mean was 2.53 with standard deviation scores of 1.28 suggesting that teachers were undecided on the statement. The findings of the study coincides with Sitati et al, (2016) that showed that outdoor areas were not free form sharp objects and harmful plants. This shows that quality education cannot be achieved where the environment appears not to be safe for children to play.

On whether their school environment compound was safe and securely fixed with playing equipments like swings, climbing frame (in one centre), merry go round (in one centre), kites, tyres, balls, ropes; neither had sand pit, $99(48.3 \%)$ of teachers disagreed that their schools had the above mentioned equipments. The computed means was $(\mathrm{M}=2.62$ and $\mathrm{SD}=1.31)$ which suggests that most public ECDE centres in West Pokot County compound were not safe and not fitted with play materials like tyres which are critical requirement for ECDE centers. Their lack of participation in sports activities was due to lack of playing kits, balls, ropes, tyres and limited area (playground) in their institutions. This problem was found to be common in majority of schools in the four sub counties as researcher observed during data collection. The results coincide with a research done by Were (2014) in Rachunyo South Sub County that established that only 10\% of pre-schools had outdoor fixed materials.

When asked as to whether their school was fenced around to provide security and minimise disruptions and interference from outside, 71 (34.6\%) of teachers agreed that their schools had fence and 68 (33.7\%) were undecided on the statement. This indicates that they were undecided $(\mathrm{M}=3.27$ and $\mathrm{SD}=1.09)$ on whether their schools were secured with fences. Observation by the researcher during the period of data collection showed that despite schools reporting to have fence, most (90\%) of them were live fence with several openings where pupils passed through when getting to school. this implied that the security of pupils for conducive learning was regularly interrupted by neighbours and animals grazing from nearby fields since they were accessing the schools. The study is somewhat different from a study conducted by Ngigi et al, (2015) in private primary schools that showed that they had developmentally appropriate learning materials, adequate play materials, safe materials, a fenced area, lockable gates, a well-maintained and clear compounds. This shows that investment in purchase and design of school outdoor resources is emphasised in private schools than public schools in Kenya.

On whether ECDE teachers conducted their lessons outside classroom, $126(61.5 \%)$ agreed. The result shows that more than $83.0 \%$ of teachers agreed $(\mathrm{M}=3.89$ and $\mathrm{SD}=0.96)$ that they conducted some of their lessons outside the classroom to ensure learners interacted with the environment. This was done especially when their learning required the learners to understand their environment, plants and even animals. Plate 6 (Appendix VII) shows an ECDE classroom ongoing under a tree to learn on nature activities. This is one of the positive outdoor classroom environmental practices that promote quality education in ECDE schools. The study coincides with Osborne (2013) research in New Zealand that showed that learning about pond ecosystems was more powerful if students visit a pond in addition to learning about them in a classroom or textbook. When asked as to whether they had enough playgrounds for their pupils, 88 (42.9\%) strongly agreed and 53 (25.9\%) agreed. From the result, it is clear that $63.9 \%$ of schools in West Pokot County public ECDE centres have enough playgrounds for learners' participation in co-curricular activities $(M=3.78$ and $S D=1.32)$. However, observation data showed that some schools did not have levelled playgrounds as the environment was surrounded by bushes while in others were rocky. 
The results coincide with Olaleye and Omoyayo (2009) research in Nigeria that showed that many of the preschools lacked portable water and conducive playgrounds for the children. The unavailability of safe playgrounds may inhibit the preschoolers to reach their perceived potential to acquire knowledge, physical and perceptual skills or competences that ensure their holistic learning and development (Macharia, 2012). Contrary to teacher responses, some head teachers during interview question No. 7 where head teacher (HT4) indicated that:

"The indoor activities have enough spaces within the classrooms. Whereas outdoor activities they have a wide open safe field for playing. Enough time has been allocated in the timetable to fit the outdoor activities."

\section{Another school head teacher (HT8) remarked that:}

"The teachers have always attended the outdoor activities without fail. The playing field is always available for ECDE pupils (nursery up to Std1-3) included. The indoor activities are only affected by limited space available in the classes."

Some of the schools observed were sharing their playing field with primary school pupils while others their playing fields were not levelled. The study finding coincides with Okudo and Omotuyole (2014) who found out that in the playful interactions, they utilize play gadgets and materials in their learning environments. Teachers trained for this level have also strongly advocated and emphasized the play- way method with an environment richly enhanced with play gadgets and materials. On whether they regularly engaged pupils in environmental activities, 89 (43.4\%) of teachers agreed with the statement. The results show that only $24.4 \%$ of teachers did not involve their pupils in cleaning compound, collecting trash, planting trees and flowers as part of their environmental studies. Most of the teachers tended to agree with the statement ( $M=3.60$ and $\mathrm{SD}=1.29$ ). The act of teachers to engage learners in environmental conservation activities at an early age will ensure that learners grow knowing the significance of protecting their environment against destruction. Composite mean with regard to outdoor environment influence on provision of quality education in public ECDE centres shows teachers were agreed $(\mathrm{M}=3.35$ and $\mathrm{SD}=1.20)$ that outdoor environmental influenced provision of quality education to ECDE pupils.

\section{Hypothesis Testing For Relationship between Outdoor Classroom Environment and Provision of Quality Education in Public ECDE Centres}

The null hypothesis stated that:

$\mathrm{H}_{04}$ There is no significant relationship between outdoor classroom environment and provision of quality education in public ECDE centres

To answer the fourth null hypothesis, a Karl Pearson correlation was computed using two-tailed test at 0.01 (99\%) significant level. The results of the analysis are presented in Table 3.

Table 3 Outdoor Classroom Environment and Provision of Quality Education

\begin{tabular}{llcc}
\hline & & Quality Education & Outdoor Classroom Environment \\
\hline & Pearson Correlation & 1 & \\
Quality Education & Pearson Correlation & $.208^{* *}$ & \\
\hline & & & \\
Outdoor Classroom Environment & Sig. (2-tailed) & 0.003 & \\
\hline **. Correlation is significant at the 0.01 level (2-tailed). & & \\
\hline
\end{tabular}

Result (Table 3) show that there exist weak positive correlation $(\mathrm{r}=0.208)$ between outdoor classroom environmental practices by teachers and provision of quality education which is significant $(\mathrm{p}<0.01)$ for two tailed-test in West Pokot County schools. This led to rejection of the null hypothesis and conclusion that there exist significant relationship between outdoor classroom environment and provision of quality education in public ECDE centres in West Pokot County, Kenya. This implies that due to unfavourable school environment (compound), teachers do not regularly conduct outside lesson in the open. If the environment was inclusive, it could promote competence, independent exploration and learning through play by ECDE children.

\section{Conclusions and Recommendations}

The objective of the research was to determine how outdoor classroom environment affected provision of quality education in public ECDE centres in West Pokot County. Learning in ECDE takes place inside and outside classroom. For instance, science, languages, sports (physical education) and environmental activities were conducted in open field, field excursions and nature observations. Therefore, teachers had a responsibility of ensuring that they consider outside learning environment to ensure provision of quality education. Children learn better through play, discovery and imitating. This is only possible if the appropriate and adequate play equipment and materials are provided to the children. Facilities that meet the needs and interest of the child should be provided and the learning environment and materials should be child-friendly, brightly coloured and 
suitable for the age of the child. This makes learning interesting and fun, motivating the child to love learning. From the study results, it was established that $83.0 \%$ of teachers conducted their lessons outside so that learners can interact with nature. The result shows that majority of ECDE teachers were aware of the importance of taking lessons outside classroom to ensure that learners interacted with their environment. Moreover, the teachers engaged pupils in environmental activities of sweeping, environmental cleaning, planting of flowers and trees. The results of the study showed that outdoor classroom environment positively influenced provision of quality education in public ECDE centres in West Pokot County. This implied that when teachers conduct activities outside classrooms, learners were able to acquire required competencies to assist in their growth and development. Both the teachers and head teachers concurred that outside environmental was critical to provision of quality education. A positive observation revealed by the study finding was that majority of teachers were able to play and interact with their children outside classrooms during sports and physical education exercises. However, it was established that despite availability of playing fields for young children, some of the fields were not levelled while others had thorny bushes and rocks making participation of children in sports and physical activities difficult. The null hypothesis was rejected $(\mathrm{p}<0.01)$ leading to the conclusion that there existed significant relationship between outdoor classroom environment and provision of quality education in public ECDE centres in West Pokot County.

There is need for head teachers to supervise and ensure that co-curricular activities are fully implemented by teachers in ECDE centres around the county outside the classroom as Education Act 2013 recommends. Teachers need to move their lesson from inside to outside the classroom to ensure learners are taught and interact with their natural environment. The school management need also to ensure that a school environment is created that has facilities for physical education, both indoor and outdoor. Sports equipments and musical instruments need also to be considered during outside classroom learning by teachers.

\section{References}

[1]. Abiero, M.O. (2013). Parental Satisfaction with the Quality of Pre-Primary Education in Bondo District, Siaya County, Kenya.MED Thesis, Kenyatta University Kenya.

[2]. Boke, R.T. (2014). Implementation of Quality Services in Early Childhood Educational Institutions: A Case of Ntimaru Division, Kuria East District. MED Project, Kenyatta University, Kenya.

[3]. Broekhuizen, K., Scholten, A-M. \& de Vries, S.I. (2014). The Value of Pre-school Playgrounds for Children's Physical Activity Level: A Systematic Review. International Journal of Behavioural Nutrition and Physical Activity, 11 (59), 1-28.

[4]. Chowdhury, A. \& Choudhury, R. (2002).Pre-school Children: Development, Care and Education. New Delhi: New age International publisher.

[5]. Curtis, A. (1998). A Curriculum for the Pre-School Child. London: Routledge.

[6]. Fuller, B. (2009). "Building Schools, Rethinking Quality? Early Lessons from Los Angeles", Journal of Educational Administration, 47 (3), 336-349.

[7]. Haile G. S. (2010). The Current Practice of Pre-school Education in some Selected Woredas of Northern Western Zone of Tigray.MA Thesis .Addis Ababa University.

[8]. Kofi, Y.A. (2012). A Comparative Study of Early Childhood Education in Selected Public and Private Pre-Schools in Kumasi. M.Phil Thesis, Kwame Nkrumah University of Science and Technology, Kumasi Ghana.

[9]. Kostelnik, M. J., Soderman, A. K., \& Whiren, A. P. (2007).Developmentally Appropriate Curriculum: Best Practices in Early Childhood Education ( $4^{\text {th }}$ Ed.). Upper Saddle River, NJ: Pearson Education, Inc.

[10]. Macharia, K.H. (2012). Influence of School Playground Safety on the Participation of Pre-School Children in Outdoor Activities in Central Division, Naivasha District, Kenya. MPhil Thesis, University of Nairobi Kenya.

[11]. Maxwell, L. E., Mitchell, M. R. \& Evans, G. W. (2008). Effects of Play Equipment and Loose Parts on Preschool Children's Outdoor Play Behaviour: An Observational Study and Design Intervention. Children, Youth and Environments, 18(2), 36-63.

[12]. Mutuma, W.M. (2015). Effectiveness of Ministry Of Education Efforts to Strengthen Early Childhood Education and Its Effect on Formal Education in Kenya. Riara University, Kenya.

[13]. Mwamba, Y., (2013). Role of School Based Factors on Quality of Education in Public Secondary Schools in Nyamira North District, Kenya. MED Project, University of Nairobi.

[14]. Mwende, L.D. (2014). School Based Factors Influencing Quality of Education in Public Secondary Schools In Kitui County, Kenya. MED Project, University of Nairobi.

[15]. Ngigi, S.K. (2015). Assessment of the Early Childhood Development Policy Implementation in Kenya, Case Study of Ruiru District. Journal of Education \& Social Policy, 2(1), 78-89.

[16]. Osborne, M. (2013).Modern Learning Environments. CORE Education's White Papers, New Zealand.

[17]. Oso, W.Y. \& Onen, D. C. (2009).A General Guide to Writing a Research Proposal and Report, the Jomo Kenyatta Foundation, Sitima printers and stationers Ltd.

[18]. Sitati, E.M., Mwangi, N., Bota K. \& Rapongo, G. S. (2016). Implementation of early childhood development education service standard guidelines on physical facilities in public and private early childhood education centres Kakamega County, Kenya. Early Child Development and Care, 186(11), 1765-1778.

[19]. UNESCO (2000).Defining Quality in Education. A Paper Presented by UNICEF st the Meeting of International Working Group on Education, Italy June 2000 .

[20]. Uwezo Kenya (2012). Are our Children Learning? Annual Learning Assessment Report. Nairobi: Uwezo Kenya.

[21]. Worthington, E. (2008). "Effective Learning Environments in ECDEs". Graduate Theses and Dissertations. Paper 10534. Available online at: http://lib.dr.iastate.edu/etd. 